\title{
A Case of Invasive Pulmonary Aspergillosis in an Immunocompetent Patient Diagnosed by EBUS-TBNA, Misdiagnosed as Lung Cancer
}

\author{
Akciğer Kanseri Olarak Yanlış Tanı Alan İmmün Sistemi Sağlıkı EBUS-TBíA ile \\ Invazif Pulmoner Aspergillozis Tanısının Konan Bir Olgu
}

Taeyun Kim', Hyunji Choi², Jinyoung Lee ${ }^{3}$, Jehun Kim

\begin{abstract}
Aspergillus species are widely distributed in nature. Aspergillus can cause life-threatening invasive pulmonary aspergillosis (IPA) in patients with impaired immune function. IPA is difficult to diagnose because the symptoms are nonspecific, and the radiologic findings can be various. A 68-year-old female was referred to the department of pulmonology for right upper chest pain for two weeks. Computedtomography (CT) scan showed suspicion of lung cancer, then endobronchial ultrasound-guided transbronchial needle aspiration (EBUS-TBNA) was performed. IPA was diagnosed histologically. In Korea, this is the first report of IPA diagnosed through EBUSTBNA. The role of EBUS-TBNA in the histological diagnosis of mass like lung lesions is expected to expand.
\end{abstract}

Key words: Endobronchial ultrasound-guided transbronchial needle aspiration, Bronchoscopy, Invasive pulmonary aspergillosis.

\section{Özet}

Aspergillozis örnekleri doğada yaygın olarak bulunmaktadır. Aspergillus, immün sistemi bozulmuş hastalarda hayatı tehdit eden invazif pulmoner aspergillozise (IPA) neden olabilmektedir. IPA semptomları nonspesifik ve radyolojik bulguları çeşitli olduğu için tanısı zor bir hastalıktır. Göğüs üst kısmında iki haftadır devam ağrı nedeniyle, 68 yaşındaki kadın hasta Göğüs Hastalıkları bölümüne yönlendirilmişti. Bilgisayarlı tomografide akciğer kanserinden şüphe edildi. Endobronşial ultrason rehberliğinde transbronşial iğne aspirasyonu (EBUS-TBIA) yapıldı ve IPA tanısı histolojik olarak kondu. Bu, Kore'de EBUS-TBIA ile IPA tanısı konan ilk olgu sunumudur. Kitlesel akciğer lezyonlarının tanısında EBUS-TBIA'nın rolünün artması beklenmektedir.

Anahtar Sözcükler: Endobronşial ultrason rehberliği, transbronşial iğne apirasyonu, bronkoskopi, invazif pulmoner aspergillozis.
'Department of Pulmonology, Kosin University Gospel Hospital, Busan, South Korea

${ }^{2}$ Department of Laboratory Medicine, Kosin University Gospel Hospital, Busan, South Korea.

${ }^{3}$ Department of Infectious Disease, Kosin University Gospel Hospital, Busan, South Korea.
${ }^{1}$ Kosin Üniversitesi Gospel Hastanesi, Göğüs Hastalıkları Bölümü, Busan, Güney Kore

${ }^{2}$ Kosin Üniversitesi Gospel Hastanesi, Tıbbi Laboratuvar

Bölümü, Busan, Güney Kore

${ }^{3}$ Kosin Üniversitesi Gospel Hastanesi, Enfeksiyon Hastalıkları Bölümü, Busan, Güney Kore

Submitted (Başvuru tarihi): 31.10.2018 Accepted (Kabul tarihi): 26.11.2018

Correspondence (iletişim): Jehun Kim, Department of Pulmonology, Kosin University Gospel Hospital, Busan, South Korea

e-mail: libertier@gmail.com

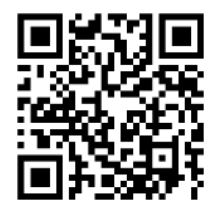


Aspergillosis refers to infectious diseases caused by fungi of the genus Aspergillus present in the residential environment, such as the soil and air (1). Invasive pulmonary aspergillosis (IPA) can be a life-threatening infectious disease for immunosuppressed patients receiving chemotherapy or recipients of stem cell transplantation (2). Early diagnosis is very challenging because IPA has similar clinical features to the usual respiratory infections (3). Clinically, identification of hyphae through a histological examination is considered the gold standard of IPA diagnosis. Endobronchial ultrasound-guided transbronchial needle aspiration (EBUS-TBNA) is a modality that is not yet commonly used to obtain the specimen. Detection of galactomannan, a component of the cell wall of Aspergillus species, in serum or bronchoalveolar lavage (BAL) fluid can also be useful for IPA diagnosis (4). Presently described is a rare case of IPA diagnosed in South Korea using EBUS-TBNA.

\section{CASE}

A 68-year-old woman presented with pain in her right upper chest present for 2 weeks. She worked in a restaurant and had no family history of respiratory disease or a smoking history. No specific previous disease had been diagnosed. She visited a local hospital on August 9, 2018 with persistent discomfort in the right upper chest. Because a chest $X$-ray revealed a suspicion of lung cancer, she visited our hospital. At the time of admission on August 12, 2018, her blood pressure was 140/80 mmHg, her pulse rate was $67 /$ minute, her respiratory rate was $16 /$ minute, and her body temperature was $36.5^{\circ} \mathrm{C}$. The

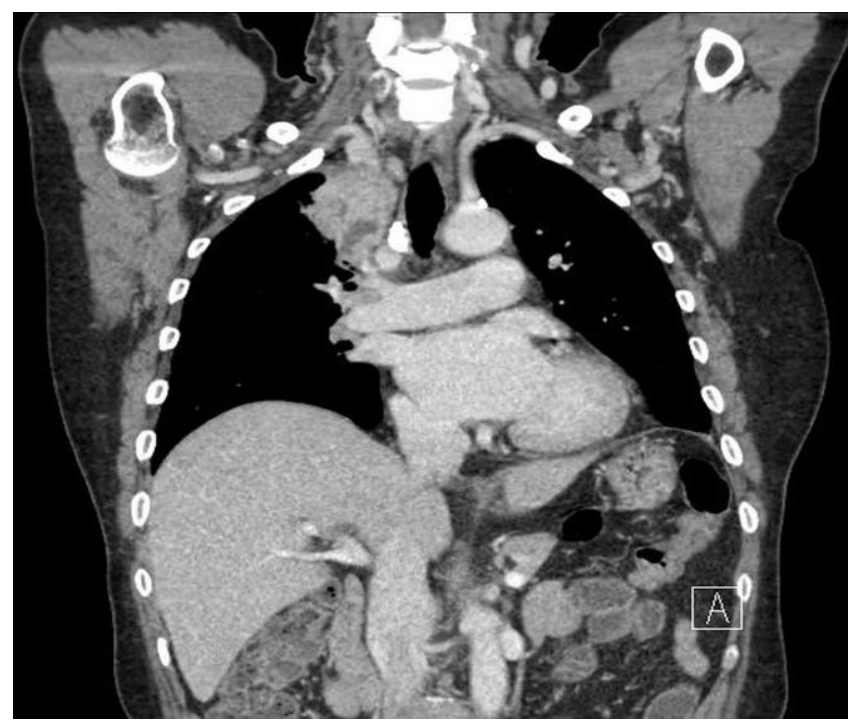

Figure 1: The coronal view of CT scan shows a mass-like consolidation of about $52 \mathrm{~mm}$ in the right upper lobe and a low-density branching structure inside the bronchus physical examination did not identify a right supraclavicular lymph node (LN) or right scalene $L N$. The peripheral blood leukocyte counts were $8970 / \mathrm{mm}^{3}$ (66.5\% neutrophils, $3.1 \%$ eosinophils, and $22.1 \%$ lymphocytes), and the platelet counts were $341,000 / \mathrm{mm}^{3}$. The blood urea nitrogen and serum creatinine level were $21.1 \mathrm{mg} / \mathrm{dL}$ and $0.34 \mathrm{mg} / \mathrm{dL}$, respectively. The aspartate transaminase and alanine aminotransferase level were $14 \mathrm{I} \mathrm{U/L}$ and 12IU/L, respectively. The high sensitivity $\mathrm{C}$-reactive protein value recorded was $0.232 \mathrm{mg} / \mathrm{dL}$. On August 13, 2018, a 5 $\mathrm{cm}$ mass-like consolidation was seen in the right upper lobe (RUL) area on the chest X-ray. On August 13, 2018, a chest computed tomography (CT) showed a mass-like consolidation of about $52 \mathrm{~mm}$ in the RUL and a lowdensity branching structure inside the bronchus. The possibility of lung cancer and an infectious condition were considered (Figure 1). Fungi were not cultured in the sputum culture or bronchoscopic washing. On August 14 2018, during a bronchoscopy, the right upper bronchus showed normal mucosal findings and no endobronchial lesion was identified. EBUS-TBNA conducted on the same day revealed a round mass $23.6 \times 26.0 \mathrm{~mm}$ in size with a hypoechoic, homogenous shadow in the right upper high paratracheal lesion, and needle aspiration was performed (Figure 2). A histological examination on August 16, 2018 indicated that the epithelium of the bronchial mucosal wall was desquamated and accompanied by exudative debris, which is a finding suggesting IPA (Figure 3). On another histological examination, hyphae that were septate and branching to acute angles were confirmed, which is also an aspergillosis finding (Figure 4).

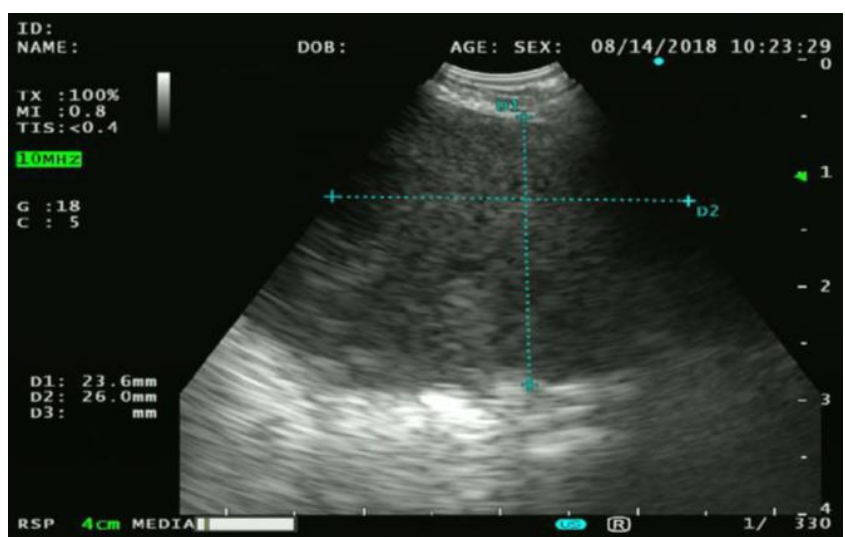

Figure 2: Convex probe EBUS shows a round shape mass with a $23.6 \times 26.0 \mathrm{~mm}$ sized hypoechoic homogenous shadow that was found in the right upper high paratracheal lesion 


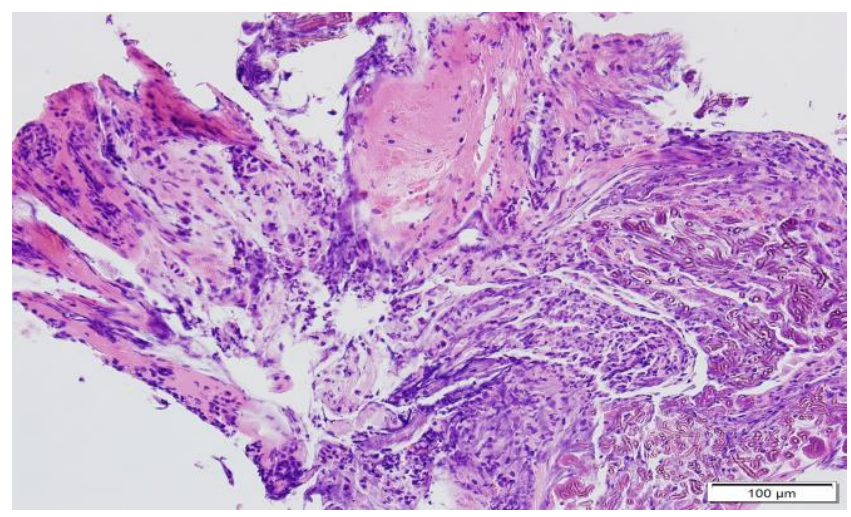

Figure 3: Histopathologic image. Septated and acute angle branching of hyphae with desquamated bronchial mucosal wall and exudative debris favoring invasive pulmonary aspergillosis (H\&E stain, $x 200$ )

To treat the IPA, intravenous voriconazole was administered at a dose of $6 \mathrm{mg} / \mathrm{kg} \mathrm{q} 12 \mathrm{~h} \times 2$ doses for induction and $4 \mathrm{mg} / \mathrm{kg} \mathrm{q} 12 \mathrm{~h}$ for maintenance from August 16, 2018 to September 12, 2018. After treating the IPA with voriconazole for 4 weeks, a chest $X$-ray taken on September 11, 2018 showed a decreased focal consolidation lesion in the median portion of the RUL zone (Figure 5). After discharge from the hospital, the patient received additional voriconazole perorally for 6 weeks.

\section{DISCUSSION}

IPA is an important contributor to death in transplant patients and neutropenic patients. Aspergillus fumigatus is the most common strain of IPA, accounting for $80 \%$ to $90 \%$ of cases, but infection by non-fumigatus species is also increasing. Infections caused by Aspergillus flavus or Aspergillus terreus have particularly increased (5). However, since the diagnosis of IPA remains challenging, an early diagnosis of IPA in immunocompromised patients is very difficult. The symptoms are nonspecific. Fever, cough, sputum, pleuritic chest pain or hemoptysis may occur (6). In a single-center study of 37 patients in Korea with diagnosed IPA, $94.6 \%$ of the patients complained of fever and chill, $27 \%$ of the patients reported cough and sputum, $10.8 \%$ of the patients had hemoptysis, and $10.8 \%$ of the patients complained of dyspnea (3).

According to the European Organization for Research and Treatment of Cancer criteria, "proven IPA" is diagnosed when histopathological evidence of fungal infection is present. "Probable IPA" is diagnosed when the host factor of immunodeficiency and the clinical features and mycological criteria seen on CT scan are satisfied. If the mycological criteria are not met, it is diagnosed as "possible IPA" (7). Among the patients diagnosed with IPA, "proven IPA" was determined in 2.7\%, "probable IPA" in $59.5 \%$,

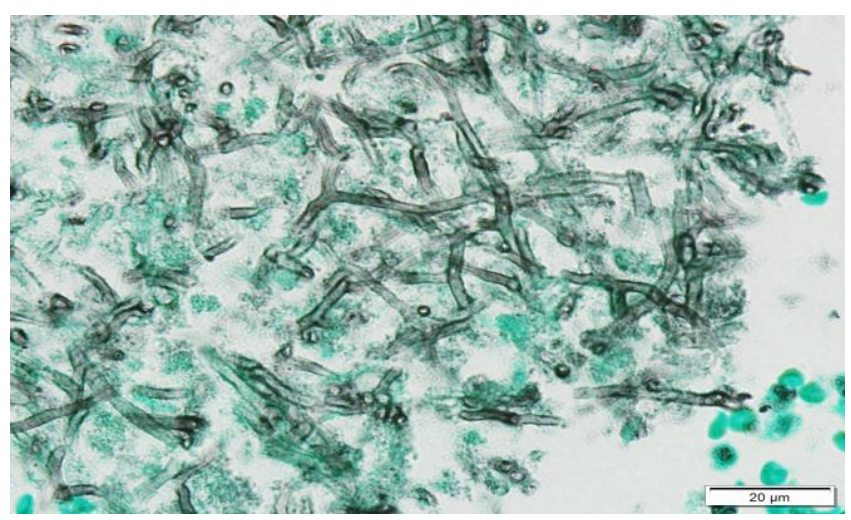

Figure 4: Histopathologic image. Fungal hyphae with acute angle branching favoring aspergillosis (GMS stain, x1000)

and "possible IPA" in 37.7\%. Histological diagnosis of IPA can be difficult (3). We performed a transbronchial lung biopsy and aspiration with EBUS-TBNA. The epithelium of the bronchial mucosal wall was not visible and necrotic materials were present, which was consistent with invasive aspergillosis.

Significant events in the histological features of lungs infected by Aspergillus occur early in the infection. Pulmonary macrophages can be used to establish the timeline after 4 hours. Early germination and progressive hyphal extension are seen after 8 to 16 hours. Dense inflammatory aggregates may also be observed. It is possible to detect galactomannan, an antigen of Aspergillus, in the patient's serum 24 hours after infection (8). Histological features of IPA also include angioinvasion, hemorrhagic infarction, intra-alveolar hemorrhage, coagulative necrosis, granuloma, and inflammatory necrosis In non-neutropenic patients, inflammatory necrosis has been reported in $50 \%$ of cases, and intra-alveolar hemorrhage in $50 \%$.

The Infectious Diseases Society of America guideline includes a "strong recommendation, high quality evidence" for additional chest CT imaging when IPA is suspected (9). The most important imaging finding in IPA is a macronodule ( $\geq 1 \mathrm{~cm}$ in diameter), which is reported in $94.5 \%$ of cases. Other radiological findings include the halo sign (60.9\%), consolidation (30.2\%), infarct-shaped macronodule (26.8\%), and a cavitary lesion (20.4\%) (10). Bronchoscopy with BAL is recommended as a "strong recommendation, moderate quality evidence." It is possible to identify a serum biomarker, such as galactomannan, which is usually easy to access, and to conduct a galactomannan antigen test on a BAL sample (11). 

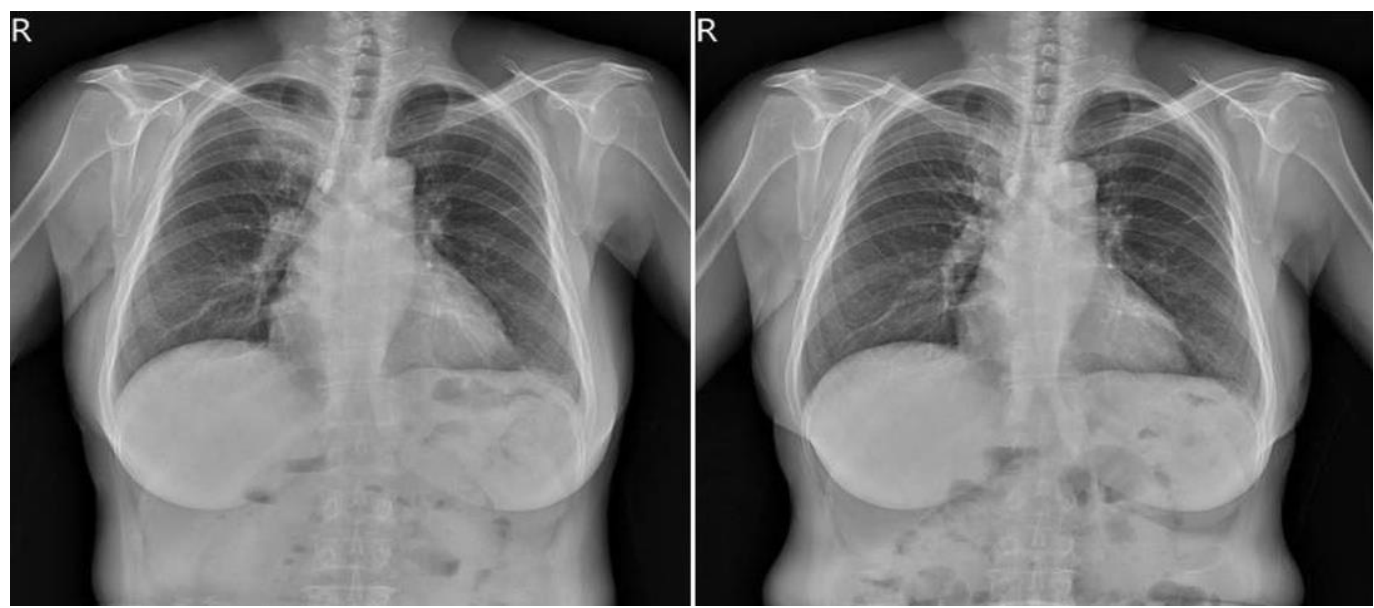

Figure 5: Chest X-ray (right) shows interval decreased extent of focal consolidative lesion in the right upper lung zone, medial portion compared to the previous film (left)

The sensitivity has been determined to be $43 \%$ and the specificity up to $100 \%$ when cultured with a macronodule. The sensitivity has been reported to be between 0 and $80 \%$ and the specificity $65 \%$ to $95 \%$ when a galactomannan assay is performed with BAL fluid. The sensitivity of a serum galactomannan assay tested using an enzymelinked immunosorbent assay has been reported to be $90 \%$ to $93 \%$, with a specificity of $95 \%$ to $98 \%$ (9). Cazzadori et al. (12) reported a higher rate of detection with transbronchial biopsy than bronchoscopy with BAL to confirm pulmonary infiltration. Transbronchial biopsy was routinely recommended for diagnosis.

EBUS-TBNA has been used for staging lung tissue from the mediastinum and hilar lesion using $35^{\circ}$ to $45^{\circ}$ forward oblique EBUS scopes (13). The sensitivity and specificity of EBUS-TBNA for lung cancer diagnosis and staging has been reported at $93 \%$ (95\% confidence interval [Cl]: 0.91-0.94) and 100\% (95\% Cl: 0.99-1.00), respectively (14). The role of EBUS-TBNA is now expanding beyond use in the diagnosis of lung cancer. It can be used for the diagnosis of early stage sarcoidosis (15), amyloidosis (16), malignant pleural mesothelioma (17), and lymphadenopathy caused by tuberculosis (18). To the best of our knowledge, only a few cases of IPA diagnosed via EBUS-TBNA have been reported. Casal et al. (19) reported invasive aspergillus tracheobronchitis with a circumferential narrowing lesion in an immunocompromised patient diagnosed with a second bronchoscopy and EBUS-TBNA. Histologically proving IPA is still very challenging. Several modalities have been used to obtain sample tissue; however, it is expected that the role of EBUS-TBNA will grow in cases of suspected IPA.

\section{CONFLICTS OF INTEREST}

None declared.

\section{AUTHOR CONTRIBUTIONS}

Concept - T.K., H.C., J.L., J.K.; Planning and Design T.K., H.C., J.L., J.K.; Supervision - T.K., H.C., J.L., J.K.; Funding - ; Materials - T.K.; Data Collection and/or Processing - T.K., H.C.; Analysis and/or Interpretation - T.K., H.C.; Literature Review - T.K., J.L.; Writing - T.K.; Critical Review - J.K.

\section{YAZAR KATKILARI}

Fikir - T.K., H.C., J.L., J.K.; Tasarım ve Dizayn - T.K., H.C., J.L., J.K.; Denetleme - T.K., H.C., J.L., J.K.; Kaynaklar - ; Malzemeler - T.K.; Veri Toplama ve/veya İşleme - T.K., H.C.; Analiz ve/veya Yorum - T.K., H.C.; Literatür Taraması - T.K., J.L.; Yazıyı Yazan - T.K.; Eleştirel Inceleme - J.K.

\section{REFERENCES}

1. Jung JY, Kim MS, Park JY, Cho EB, Park EJ, Kim KH, et al A Case of Cutaneous Aspergillus flavus Infection in an Immunocompetent Patient. Korean J Med Mycol 2016; 21:20-5. [CrossRef]

2. Kristan SŠ, Kern I, Mušič E. Invasive pulmonary aspergillosis. Respiration 2002; 69:521-5. [CrossRef]

3. Park SY, Lee EJ, Kim TH, Choo EJ, Jeon MH, Kong MG, et al. The Clinical Characteristics, Therapeutic Outcome and Prognostic Factors for Invasive Pulmonary Aspergillosis: A Single-Center Experience and Review of the Literature. Korean J Med Mycol 2012; 17:17-24. [CrossRef] 
4. Song JG, Kang SH, Jung BW, Oh HS, Kim MJ, Lee SH. Invasive Pulmonary Aspergillosis Histologically Mimicking Mucormycosis. Ewha Med J 2016; 39:65-8. [CrossRef]

5. Garnacho-Montero J, Olaechea P, Alvarez-Lerma F, Alvarez-Rocha L, Blanquer J, Galván B, et al. Epidemiology, diagnosis and treatment of fungal respiratory infections in the critically ill patient. Rev Esp Quimioter 2013; 26:173-88.

6. Jeong DW, Lee S-H, Moon J-Y, Kim Y-G, Lee YH, Kim K, et al. Fatal Invasive Pulmonary Aspergillosis after Combined Induction with Rituximab and Antithymocyte Globulin for Kidney Transplantation in a Sensitized Recipient, and Early Rejection Therapy with Plasmapheresis and Low-dose Immunoglobulin. J Korean Soc Transplant 2017; $31: 52-7$. [CrossRef]

7. De Pauw B, Walsh TJ, Donnelly JP, Stevens DA, Edwards $J E$, Calandra $T$, et al. Revised definitions of invasive fungal disease from the European organization for research and treatment of cancer/invasive fungal infections cooperative group and the national institute of allergy and infectious diseases mycoses study group (EORTC/MSG) consensus group. Clin Infect Dis 2008; 46:1813-21. [CrossRef]

8. Hope WW, Petraitis V, Petraitiene R, Aghamolla T, Bacher J, Walsh TJ. The initial 96 hours of invasive pulmonary aspergillosis: histopathology, comparative kinetics of galactomannan and $(1 \rightarrow 3)-\beta$-d-glucan, and consequences of delayed antifungal therapy. Antimicrob Agents Chemother 2010; 54:4879-86. [CrossRef]

9. Reichenberger F, Habicht JM, Gratwohl A, Tamm M. Diagnosis and treatment of invasive pulmonary aspergillosis in neutropenic patients. Eur Respir J 2002; 19:743-55. [CrossRef]

10. Greene RE, Schlamm HT, Oestmann J-W, Stark P, Durand $\mathrm{C}$, Lortholary $\mathrm{O}$, et al. Imaging findings in acute invasive pulmonary aspergillosis: clinical significance of the halo sign. Clin Infect Dis 2007; 44:373-9. [CrossRef]

11. Patterson TF, Thompson GR 3rd, Denning DW, Fishman JA, Hadley S, Herbrecht R, et al. Practice guidelines for the diagnosis and management of aspergillosis: 2016 update by the Infectious Diseases Society of America. Clin Infect Dis 2016; 63:e1-e60. [CrossRef]

12. Cazzadori A, Di Perri G, Todeschini G, Luzzati R, Boschiero L, Perona $G$, et al. Transbronchial biopsy in the diagnosis of pulmonary infiltrates in immunocompromised patients. Chest 1995; 107:101-6. [CrossRef]

13. Xiang Y, Zhang F, Akulian J, Yarmus L, Feller-Kopman D, Wang KP. EBUS-TBNA by a new Fuji EBUS scope (with video). J Thorac Dis 2013; 5:36. [CrossRef]

14. Gu P, Zhao Y-Z, Jiang L-Y, Zhang W, Xin Y, Han B-H. Endobronchial ultrasound-guided transbronchial needle aspiration for staging of lung cancer: a systematic review and meta-analysis. Eur J Cancer 2009; 45:1389-96. [CrossRef]

15. Wong M, Yasufuku K, Nakajima T, Herth FJ, Sekine Y, Shibuya $K$, et al. Endobronchial ultrasound: new insight for the diagnosis of sarcoidosis. Eur Respir J 2007; 29:1 182-6. [CrossRef]

16. Fujiwara T, Yasufuku K, Nakajima T, Chiyo M, lyoda A, Yoshida $S$, et al. Primary amyloidosis involving mediastinal lymph nodes diagnosed by EBUS-TBNA. Respir Med CME 2009; 2:51-3. [CrossRef]

17. Senturk A, Parlak ES, Babaoglu E, Tatli Dogan H, Hasanoglu HC. Malignant Pleural Mesothelioma Detected by Endobronchial Ultrasound-Guided Transbronchial Needle Aspiration. Respir Case Rep 2016; 5:178-80. [CrossRef]

18. Navani N, Molyneaux PL, Breen RA, Connell DW, Jepson A, Nankivell $M$, et al. Utility of endobronchial ultrasoundguided transbronchial needle aspiration in patients with tuberculous intrathoracic lymphadenopathy: a multicentre study. Thorax 2011 ; 66:889-93. [CrossRef]

19. Casal RF, Adachi R, Jimenez CA, Sarkiss M, Morice RC, Eapen GA. Diagnosis of invasive aspergillus tracheobronchitis facilitated by endobronchial ultrasound-guided transbronchial needle aspiration: a case report. J Med Case Rep 2009; 3:9290. [CrossRef] 